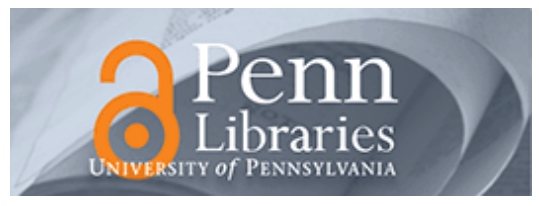

University of Pennsylvania ScholarlyCommons

January 2002

\title{
Creating a Positive Future for a Minority Community: Transportation and Urban Renewal Politics in Miami
}

\author{
Milan Dluhy \\ University of North Carolina, Wilmington \\ Keith Revell \\ Florida International University \\ Sidney Wong
}

Follow this and additional works at: https://repository.upenn.edu/penniur_papers

Dluhy, Milan; Revell, Keith; and Wong, Sidney, "Creating a Positive Future for a Minority Community: Transportation and Urban Renewal Politics in Miami" (2002). Penn IUR Publications. 14.

https://repository.upenn.edu/penniur_papers/14

Copyright Urban Affairs Association. Reprinted from Journal of Urban Affairs, Volume 24, Issue 1, January 2002, pages 75-95. Sidney Wong was a faculty member in the Department of City \& Regional Planning, University of Pennsylvania, from 2000 to 2007.

This paper is posted at ScholarlyCommons. https://repository.upenn.edu/penniur_papers/14

For more information, please contact repository@pobox.upenn.edu. 


\title{
Creating a Positive Future for a Minority Community: Transportation and Urban Renewal Politics in Miami
}

\author{
Abstract \\ Overtown, once the center of African American life in Miami, lost $40 \%$ of its population when Interstate 95 \\ was built through the heart of the community in the 1960s. Even though a variety of non-policy factors \\ played a role in the decline of the area, expressway construction and urban renewal greatly accelerated \\ the process. Just as important, efforts to mitigate the impact of the highway were delayed for many \\ years, thus magnifying the negative effects of public policies. The political barriers preventing the \\ redevelopment of Overtown are described and analyzed. The future of Overtown is critically examined \\ and evaluated.

\section{Comments} \\ Copyright Urban Affairs Association. Reprinted from Journal of Urban Affairs, Volume 24, Issue 1, January \\ 2002, pages 75-95. Sidney Wong was a faculty member in the Department of City \& Regional Planning, \\ University of Pennsylvania, from 2000 to 2007.
}




\title{
CREATING A POSITIVE FUTURE FOR A MINORITY COMMUNITY: Transportation and Urban Renewal Politics in Miami
}

\author{
MILAN DLUHY \\ University of North Carolina, Wilmington \\ KEITH REVELL \\ Florida International University \\ SIDNEY WONG \\ University of Pennsylvania
}

\begin{abstract}
Overtown, once the center of African American life in Miami, lost $40 \%$ of its population when Interstate 95 was built through the heart of the community in the 1960s. Even though a variety of non-policy factors played a role in the decline of the area, expressway construction and urban renewal greatly accelerated the process. Just as important, efforts to mitigate the impact of the highway were delayed for many years, thus magnifying the negative effects of public policies. The political barriers preventing the redevelopment of Overtown are described and analyzed. The future of Overtown is critically examined and evaluated.
\end{abstract}

In March 1996, the Metropolitan Planning Organization (MPO) of Miami-Dade County made a very expensive decision to re-route the planned multi-million dollar East-West Multi-Modal commuter rail line around the historically black neighborhood of Overtown. The community lies just to the northwest of downtown Miami. The new route, should the project ever be built, will take the East-West line through a $\$ 300$ million tunnel to the south of Overtown to avoid any adverse effects on this African American community. The tunnel option was chosen largely in response to the objections of Overtown political activists who maintained that the area had suffered at the hands of policymakers for decades. They claimed that the construction of Interstates

Direct correspondence to: Keith Revell, College of Health and Urban Affairs, Department of Public Administration, Florida International University, University Park, ECS-450, 11200 S.W. 8th Street, Miami, FL 33199. E-mail: revellk@fiu.edu

JOURNAL OF URBAN AFFAIRS, Volume 24, Number 1, pages 75-95.

Copyright (C) 2002 Urban Affairs Association

All rights of reproduction in any form reserved.

ISSN: 0735-2166. 
95 and 395 in the mid-1960s transformed Overtown from a stable middle- and working-class neighborhood and a center for black life and culture (once known as "the Harlem of the South") into a typical inner-city slum. They argued that the expressway, and the urban renewal efforts that followed, intentionally displaced some 40,000 residents, uprooted longtime homeowners, and destroyed a thriving business district. As reparations for the disastrous effects of past policies, they insisted, Overtown should be spared any further impact by new transportation projects and should be given significant economic development assistance to right the wrongs of governmental decisions made nearly 40 years ago (MPO, 1996a; MPO, 1996b).

Policymakers could not, and did not, take this intrusion of the past into the present lightly. Even a cursory look at a map of Overtown reveals the profound physical impact of the highways. The story of the deliberate destruction of Overtown by I-95 is well known in Miami and elsewhere (Blackside, 1990; Mohl, 1993). Although this was not the first time that Overtown activists discussed the issue of reparations, the East-West project did mark the first time since the 1960s that transportation planners showed any interest in the future of the community. For public officials, demonstrating a causal link between the physical changes wrought by the expressway and the subsequent decline of the community became a crucial policy question. Establishing causation was tantamount to assigning blame and assigning blame was the first step toward making a case for restitution. If successful, the amount of restitution could be substantial. As numerous former and current residents contended, the destruction of this community of doctors, lawyers, shopkeepers, entertainers, and hotel owners was in fact the culmination of a long history of negative governmental acts-slavery, the Dred Scott decision, Plessy v. Ferguson, Jim Crow-which had unjustly burdened African Americans. The history of Overtown, according to community leaders and activists, represented a textbook case of the need for environmental justice. Commissioner Art Teele (the only African American on the MPO) championed this position. He insisted that transportation planners were obliged to spare Overtown from further destruction by rerouting the new rail line while at the same time undertaking an array of retroactive mitigation efforts. These efforts should include the provision of resources from the East-West project to repair and redevelop parts of Overtown that had been affected by the prior construction of the interstate highways.

This article explains why prior transportation and urban development policies continue to shape land use decisions in Overtown. So much has happened since Overtown's heyday in the 1940s that sorting out the causal linkages among the multiple public policies, dramatic demographic transitions, and profound cultural changes of the last half-century is no easy task. While assigning blame for Overtown's decline solely to the I-95/395 highway project is an oversimplification, it is undeniable that public authorities must accept some responsibility for what happened and continues to happen there. Compared to Miami, other cities such as Jacksonville, Nashville, New Orleans, and Tampa have more successfully managed similar situations. It is our contention that public action and inaction since the mid-1960s greatly amplified the negative effects upon Overtown of expressway construction and urban renewal. While local public officials applauded the benefits of the I-95/395 transportation project for the community at large, they minimized the negative consequences for Overtown. While not directly articulating a trade-off, local public officials implied that moving people and goods back and forth between the suburbs and downtown was certainly more important than the destruction of a small minority enclave. In light of a new East-West transportation project, however, the issue of how decision-makers managed prior projects re-emerged, and they were asked to assume responsibility for contributing to the demise of the neighborhood and not repeat prior mistakes.

The story of Overtown provides important lessons about past management and policy implementation failures, and how prior political controversies over land use can be used to shape 
current policies. The fate of Overtown also suggests ways in which advocacy planners and community activists can be more effective in seeking ways to secure a future for communities that suffered the worst impacts of massive transportation projects and urban renewal during the 1960s and 1970s. In order to provide a comprehensive history of Overtown's rise and fall, we have used a multiple-method approach, including the following:

1. An analysis of census information for Overtown and the surrounding areas for the period between 1950 and 1990 to ascertain internal demographic changes and population movements in the region,

2. Exploration of newspaper, audio-visual, and other archival materials to establish the chronology of the urban renewal, freeway, and other public policy measures that impacted Overtown,

3. Key informant interviews with decision-makers and planners involved in the policy process,

4. An oral history project that included interviews with 57 former and current residents of Overtown to document their perceptions of changes in the area,

5. Construction of a historical business profile of Overtown for the period between 1949 and 1989 to reconstruct economic trends and identify key periods of change,

6. A meta-analysis of studies, reports, plans, and proposals relating to housing and economic development after Overtown was impacted by transportation and urban renewal projects,

7. A comparative study of transportation projects and mitigation strategies in Jacksonville, Nashville, New Orleans, and Tampa over the same period of time.

By using these multiple methods, we can provide a more comprehensive assessment of the impact of a range of public policies on land use in Overtown and identify more accurately those factors that have caused land use controversies to linger as a policy problem.

\section{THE CASE OF OVERTOWN}

The decline of Overtown has been attributed primarily to the role of public policies that radically changed land use during the mid-1960s. The population of this small ( 0.73 square miles), dense area actually grew during the 1950 s, reaching a historical peak of nearly 33,000 in 1960. By 1970, however, the population declined by half, beginning a trend that left the area with fewer than 8,000 residents by 1990 . This decline in population was mirrored by a drop in the number of local businesses located by the expressway, about one-quarter of which were forced to close in the late 1960s. Long gone are the nightclubs and hotels that once made Overtown the "Harlem of the South." Today, the community has few long-time residents, an almost non-existent business sector, some of the most dilapidated housing in the county, one of the highest crime rates in the city, and a reputation as a center for the drug trade. Table 1 shows selected demographic characteristics currently found in Overtown.

The demographic and economic transformations of Overtown appear to coincide with expressway construction and urban renewal, which occurred during the mid-1960s and displaced (collectively) about 12,000 residents. Although the impact of expressway construction and urban renewal did not result in the displacement of 40,000 people as claimed in some popular accounts of Overtown's demise, their influence was nonetheless very significant as they clearly appeared to initiate the downward trend that accounts for the area's present condition (Dluhy, Cattan, Revell, Strube, \& Wong, 1998). However, because the decline of Overtown occurred over a long and eventful period of time, it is important to look beyond the dramatic 
TABLE 1

A Demographic Profile of Overtown and the Miami Metropolitan Area

\begin{tabular}{lcc}
\hline & $\begin{array}{c}\text { Overtown } \\
\text { (Percentage) }\end{array}$ & $\begin{array}{c}\text { Miami-Dade County } \\
\text { (Percentage) }\end{array}$ \\
\hline Unemployment rate & 19.8 & 12.6 \\
Upper white collar workers & 12.5 & 20.0 \\
Lower white collar workers & 19.3 & 26.5 \\
Upper blue collar workers & 6.1 & 8.6 \\
Lower blue collar workers & 22.9 & 17.1 \\
Service workers & 34.4 & 25.6 \\
Persons with no high school diploma & 59.8 & 44.0 \\
Persons with high school diploma & 36.8 & 46.1 \\
Persons with college diploma or beyond & 3.4 & 9.9 \\
Families in poverty & 51.3 & 26.8 \\
Children in poverty & 64.9 & 38.9 \\
On public assistance & 31.6 & 14.7 \\
Total population & 7,961 & 397,993 \\
\hline
\end{tabular}

Source: Cattan, 1998.

changes of the mid-1960s to see the full range of policy and non-policy factors that shaped its current status.

\section{Demographic and Economic Changes Prior to Interstate Construction}

The decline of American center cities began prior to the mid-1960s (Sugrue, 1996). By the early 1950s, multiple explanations had been developed to explain the persistent deterioration of the urban core (Woodbury, 1953). In particular, the years immediately after World War II witnessed tremendous suburbanization. Partly as the result of the population explosion of the baby boom generation and partly as a response to the pent-up demand for better housing since the Great Depression, new housing mushroomed on the urban fringe. Vernon (1959) concluded from a 13-city study that central cities were obsolete and could not compete with the suburbs. Upwardly mobile families were moving out either for larger, more affordable housing then available in the suburbs or for the perceived better living conditions outside the center city.

During the same period, the rural urban migration of African Americans into metropolitan areas further affected inner-city neighborhoods. While most analyses of black migration focused on northern industrial cities, evidence suggests that southern cities were equally impacted by successive waves of black immigration from the rural areas. This influx of population created tremendous stress on the segregated ghettos that, unlike the northern counterparts, had little room for expansion (Mohl, 1995).

Although Miami (then a growing sunbelt city) did not fit the profile of the prototypical industrial cities that served as the models of urban decline in the 1950s and 1960s, Overtown did. As the congested economic, cultural, and residential center for the black population of Miami, Dade County, and the entire South Florida region from 1896 to the mid-1960s, Overtown was affected by many of the same trends that threatened center city areas in the northeastern and mid-western United States. In the two decades after World War II, Overtown was subjected to changes involving both policy and non-policy factors, including (a) uncontrolled 
residential decentralization, (b) dramatic internal demographic turnover, and (c) the erosion of the area's economic base. Together, these changes weakened the social fabric and eroded the distinctive sense of community autonomy in Overtown, thus rendering it all the more vulnerable to the effects of expressway construction and urban renewal.

Two key trends, decentralization and in-migration, undermined Overtown's position as the undisputed center of black Miami in the postwar years. Because of racial segregation and discrimination, African Americans in South Florida were confined to a handful of places for the first half of the twentieth century and Overtown was, consequently, the hub of black economic and cultural life. Although a mere 468 acres, Overtown was by far the largest black settlement in South Florida, accommodating about 29,000 persons in 1950 and growing to 33,000 in 1960. However, the combined result of out-migration from Overtown into new black residential areas in the County and the in-migration of poor blacks from southern states into the region significantly weakened the relative importance of Overtown as a major black neighborhood in Miami. As Table 2 illustrates, between 1950 and 1960 the number of black residents living in Dade County outside Overtown increased from 36,000 to 105,000, a net gain of 69,000 or nearly double the black population in 1950 . Over this same period, the population within Overtown increased only marginally. As a result, the percentage of the County's black population living in Overtown decreased from 45\% to 24\% between 1950 and 1960. By 1960, Liberty City, the African American suburban area to the north of downtown Miami and Overtown, had 10,000 more residents than Overtown. Likewise, within the city limits, almost $75 \%$ of Miami's black residents lived in Overtown in 1950; ten years later, this percentage dropped to 50\%. The data show that large-scale demographic changes were shifting the center

\section{TABLE 2}

The Decline of Overtown in Comparison With Other Black Areas in Miami-Dade County

\begin{tabular}{|c|c|c|c|c|c|c|}
\hline & 1950 & 1960 & 1970 & 1980 & 1990 & 2000 \\
\hline \multicolumn{7}{|l|}{ Number of African American Residents } \\
\hline Overtown & 29,253 & 32,665 & 15,935 & 10,109 & 7,961 & 6,329 \\
\hline Other neighborhoods within city limits & $\underline{11,009}$ & 32,548 & 60,221 & 77,001 & 90,246 & 74,529 \\
\hline City of Miami & $\overline{40,262}$ & 65,213 & 76,156 & 87,110 & 98,207 & 80,858 \\
\hline Suburbs & $\underline{24,685}$ & 72,086 & $\underline{113,510}$ & $\underline{193,324}$ & $\underline{299,786}$ & $\underline{376,356}$ \\
\hline Dade County & $\overline{64,947}$ & $\overline{137,299}$ & $\overline{189,666}$ & $\overline{280,434}$ & $\overline{397,993}$ & $\overline{457,214}$ \\
\hline \multicolumn{7}{|l|}{ Percentage Distribution as of City of Miami } \\
\hline Overtown & 72.7 & 50.1 & 20.9 & 11.6 & 8.1 & 8.5 \\
\hline Other neighborhoods within city limits & 27.3 & 49.9 & 79.1 & 88.4 & 91.9 & 91.5 \\
\hline \multicolumn{7}{|l|}{ Percentage Distribution as of Dade County } \\
\hline Overtown & 45.0 & 23.8 & 8.4 & 3.6 & 2.0 & 1.4 \\
\hline Other neighborhoods within city limits & 17.0 & 23.7 & 31.8 & 27.5 & 22.7 & 16.3 \\
\hline Surburbs & 38.0 & 52.5 & 59.8 & 68.9 & 75.3 & 82.3 \\
\hline \multicolumn{7}{|l|}{ Absolute and Percentage Changes } \\
\hline Population in Overtown & 29,253 & 32,665 & 15,935 & 10,109 & 7,961 & 6,329 \\
\hline Absolute change & & 3,412 & $-16,730$ & $-5,826$ & $-2,148$ & $-1,632$ \\
\hline Percentage change & & 11.7 & -51.2 & -36.6 & -21.2 & -20.0 \\
\hline Population in the county outside Overtown & 35,694 & 104,634 & 173,731 & 270,325 & 390,032 & 450,885 \\
\hline Absolute change & & 68,940 & 69,097 & 96,594 & 119,707 & 60,853 \\
\hline Percentage change & & 193.1 & 66.0 & 55.6 & 44.3 & 15.6 \\
\hline
\end{tabular}

Source: Cattan (1998). 
of gravity in black Miami away from Overtown to other non-contiguous black residential areas, even before expressway construction and urban renewal displaced a sizeable portion of its population. Unlike Chicago's South Side or New York's Harlem, in-migration in Miami did not create a very large central black residential area; instead, it dispersed new residents to other areas, fragmenting black political power, and weakening rather than strengthening Overtown's role in the expanding community.

While the total population of Overtown did not decline dramatically until the impacts of expressway construction and urban renewal were felt in the late 1960s, the area's internal demographic composition was also undergoing an important transformation during the 1950s. Between 1950 and 1960, about 13,000 black in-migrants arrived in Overtown, the majority came from outside the county and often from rural Florida or other southern states. As was typical of central cities in the northeast and mid-west that absorbed newcomers during the Great Migrations of the early- and mid-twentieth century, Overtown was reshaped by its new residents. Census data indicate that between 1950 and 1960, more than 4,000 new renter households were added to Overtown, decreasing the average household size from 4.6 to 3.1 persons. At the same time, about 10,000 residents, disproportionately from the prime working age group ( 25 to 54 years of age), left Overtown. This trend had an important impact on the socioeconomic makeup of the community, which already suffered from a very low rate of homeownership. In 1950, only 737 of Overtown's 6,362 households, or about 11.6\%, were owner-occupied. By 1960, there were 621 owner-occupied units in an area-a homeownership rate of only $5.9 \%$. The loss of 116 homeowners signaled the initial exodus of about oneseventh of the area's small but important propertied class. Rather than continue to live in Overtown, some of the community's home-owning elite followed the lead of many new migrants by relocating to the suburbs, such as Opa Locka, Liberty City, and Carol City in the northwest part of the county and Richmond Heights and Goulds in the southwest. The results of these trends can be seen clearly when Overtown is compared with emerging black neighborhoods in the county (see Table 3). In 1950, though most of Overtown's residents were concentrated in low-paying jobs, their income level and occupational mix were similar to other black neighborhoods. By 1960, all significant socio-economic indicators showed the population of Overtown falling behind the new suburban populations that were progressively shifting the focus of black Miami away from Overtown.

Although these changes were in large measure a result of demographic forces beyond the control of local officials, a building code enforcement effort by the city of Miami also played

TABLE 3

Economic Decline of Overtown Compared to the City of Miami

\begin{tabular}{|c|c|c|c|c|c|}
\hline & 1949 & 1959 & 1969 & 1979 & 1989 \\
\hline \multicolumn{6}{|l|}{ Current Dollar (unadjusted) } \\
\hline Overtown & $\$ 1,506$ & $\$ 2,450$ & $\$ 3,245$ & $\$ 6,174$ & $\$ 9,560$ \\
\hline City of Miami & $\$ 1,518$ & $\$ 2,635$ & $\$ 4,246$ & $\$ 8,600$ & $\$ 12,481$ \\
\hline Overtown as a percentage of Miami & 99 & 93 & 76 & 72 & 77 \\
\hline \multicolumn{6}{|l|}{ Constant 1989 Dollars } \\
\hline Overtown & $\$ 7,749$ & $\$ 10,440$ & $\$ 10,964$ & $\$ 10,545$ & $\$ 9,560$ \\
\hline Percentage Change & & 34.7 & 5.0 & -3.8 & -9.3 \\
\hline City of Miami & $\$ 7,810$ & $\$ 11,228$ & $\$ 14,346$ & $\$ 14,689$ & $\$ 12,481$ \\
\hline Percentage Change & & 43.8 & 27.8 & 2.4 & -15.0 \\
\hline
\end{tabular}

Note: Figures represent the median income for black households by neighborhood grouping.

Source: Cattan (1998). 
a very important role in the residential transformation of Overtown in the 1950s. That effort resulted in the destruction of the so-called shotgun shacks (one-bedroom wooden houses) that were the main form of housing in Overtown. They were replaced with concrete monsters, ugly, shoddily constructed, two- to three-story apartment buildings, usually owned by absentee landlords. As illustrated in Table 4, code enforcement fueled a speculative apartment boom between 1949 and 1962, with the number of apartments increasing 25 fold in that 13-year period. And while it was true that the old shotgun shacks were usually rental units, the switch from single-family wooden structures to multi-family apartments made it appear as though Overtown was being transformed from an area of homeowners to an area of renters, thus exaggerating the social changes taking place in the community. As one resident who was born in Overtown in 1932 and moved out in 1950 recalled: "that faction that started moving in were naturally not like the people who were homeowners there and they started coming in with these apartments and Overtown has never been the same since." The presence of homeowners and the appearance of single-family homes strongly suggested that Overtown was a place of permanent residents, rather than transients, and the profusion of apartment buildings in the wake of code enforcement made it much more difficult to see Overtown in those terms.

Economic changes were also disrupting the sense of cohesion and autonomy that made Overtown a community. Because most of Overtown's residents worked outside of the area, the economic fate of Overtown was tied to conditions beyond its borders. Changes in traditional employment centers, such as the old port of Miami, which was located between Biscayne Bay and the tracks of the Florida East Coast (FEC) Railroad (the eastern boundary of Overtown), negatively affected local employment opportunities. When the port was relocated to a more modern facility on an offshore island in early 1960s, it very likely had an impact on the earning power of Overtown residents. The decline of the FEC, which brought many of the first blacks to Miami, similarly affected employment prospects. The influx of Cuban immigrants during the 1960s also initiated job conflict and competition with the residents of Overtown. Although there is still considerable debate over whether immigrants displaced blacks from lowwage jobs or whether blacks vacated those positions first, it is apparent that immigration brought with it a new level of competition for jobs in the low-wage service and construction industries in the Miami metropolitan area.

By far the most important economic change, however, could be seen on the streets of Overtown itself. During the postwar period, businesses followed their wage-earning customers to newly opened black neighborhoods like Liberty City, which was developing its own commercial centers during the 1950s and early 1960s. This translated into a corresponding decline in the concentration of businesses in Overtown. Between 1949 and 1966, the number of business establishments in the three street commercial heart of Overtown declined from 380 to 289 , a loss of $28 \%$ (see Table 5). Although this decline was quite gradual (about $2 \%$ of the

\section{TABLE 4}

Overtown Apartment Boom: 1949 to 1960

\begin{tabular}{lcccccc}
\hline Year & 1949 & 1954 & 1960 & 1962 & 1966 & 1970 \\
\hline NW 2nd Avenue & 1 & 5 & 17 & 17 & 17 & 17 \\
NW 3rd Avenue & 2 & 8 & 19 & 24 & 24 & 11 \\
NW 14th Street & $\frac{1}{4}$ & $\frac{2}{15}$ & $\frac{6}{42}$ & $\frac{8}{49}$ & $\frac{8}{49}$ & $\frac{2}{30}$ \\
Total & & & & & \\
\hline
\end{tabular}

Note: Figures represent apartment buildings in three sampled street sections.

Source: Wong, 1998a. 
TABLE 5

Decline of Businesses in Overtown, 1949 to 1989

\begin{tabular}{lccc}
\hline Year & $\begin{array}{c}\text { Number of } \\
\text { Businesses }\end{array}$ & $\begin{array}{c}\text { Absolute } \\
\text { Change }\end{array}$ & $\begin{array}{c}\text { Annualized } \\
\text { Percentage Change }\end{array}$ \\
\hline 1949 & 389 & & -1.3 \\
1954 & 365 & -24 & -2.3 \\
1960 & 318 & -47 & 2.2 \\
1962 & 332 & 14 & -3.7 \\
1964 & 308 & -24 & -2.5 \\
1966 & 293 & -15 & -22.9 \\
1967 & 226 & -67 & -7.8 \\
1969 & 192 & -34 & -14.6 \\
1970 & 164 & -28 & -2.8 \\
1972 & 155 & -9 & -7.8 \\
1976 & 112 & -43 & -15.9 \\
1980 & 56 & -56 & -3.4 \\
1989 & 41 & -15 & \\
\end{tabular}

Note: These figures are derived from a sample of the three major commercial street sections in Overtown (NW 2nd Avenue - 5th to 11th blocks; NW 3rd Avenue-11th to 19th blocks; and NW 14th Street-1st to 6th blocks).

Source: Wong, 1998a.

businesses were lost each year), its cumulative impact over 15 years was substantial. By the early sixties, several important and long-standing establishments that catered to the black community throughout South Florida, such as the Lyric Theater, Freidmark's Department Store, Philips Jewelers, and Gen Jewelers, were gone.

This gradual decline of the business district prior to the impact of the expressway had important consequences for the perception of community in Overtown. Access to a wide variety of stores and amenities had given Overtown a sense of being self-contained. Almost every resident interviewed for this study vividly recalled drugstores, movie theaters, hotels, restaurants, cleaning establishments, grocery stores, barber shops, beauty salons, and other local businesses. As one Overtown resident put it:

Oh, there were so many businesses in Overtown that you really didn't need to go downtown Miami, as we called the Flagler Street section, because everything that you really needed was in Overtown. You had the men's shop that made the men's clothing, there was a furniture store right on Second Avenue, there was Shanang's Restaurant, and there was Manerver's beauty shop. The doctors were there; the dentists were there. Any need that you had could be met in Overtown because the businesses were there.

The variety of local businesses thus gave Overtown a sense of completeness; when they began disappearing in the 1950s, that sense of economic autonomy began to decline.

Even before nearly half of Overtown's residents were uprooted in 1966 and 1967 by expressway construction and urban renewal, there were important changes in and around the area that threatened its role as a center for black life and culture. The growth of Miami's black population, the opening of new suburban areas, the in-migration of poor renters, the outmigration of homeowners, and the erosion of the business district cumulatively destabilized the community. The social, economic, and demographic transformations occurring throughout the County gradually decentered Overtown, chipping away at its prominence and disrupting 
the sense of cohesion that long-time residents recall so fondly. These trends actually made Overtown an attractive target through which to locate the expressway and made organized political resistance to urban renewal less effective.

\section{The Impact of Expressway Construction and Urban Renewal}

There can be little question that expressway construction and urban renewal had a devastating effect on Overtown. The demographic and economic changes in the 20 years before 1965 certainly weakened the community's ability to weather the impact of large-scale displacement, but even a thriving community would have had trouble resisting the political muscle behind the I-95/395 project and the urban renewal that accompanied it. In the original plans, however, Overtown would not have been affected by expressway building, as the expressway would have run over the FEC tracks, along the eastern edge of Overtown. That plan, had the railroad accepted it, would have been very expensive given the necessary clearances between railroad cars and expressway. With the passage of the National Interstate and Defense Highway Act in 1956, local and state officials, working with consulting engineers Wilbur Smith and Associates, shifted the route of the expressway to the west of the FEC tracks to a point between 6th and 7th Avenues (approximately the route it takes today). The 1956 Wilbur Smith route for the North-South expressway (later called I-95) cut through the western part of Overtown, and included an East-West expressway (later called I-395) bisecting Overtown at about 9th Street (several blocks south of its current location). There were several reasons for the choice of the westerly route including the following:

1. the battle with the FEC made it unlikely that the expressway could be built over the railroad tracks,

2. land to the west of the tracks was cheaper, in the downtown area and along the entire route (which ran through over 130 blocks of white neighborhoods to the north of Overtown),

3. it was easier to deal with a few large property owners in Overtown rather than many property owners in other sections of the downtown area, and

4. black residents in Overtown had little political voice at the time and their objections to the route were easier to disregard.

It is also notable that the State Road Board did not give much thought to the problem of residential relocation. The I-95/395 interchange was the final section of expressway to be built. By the time the State Road Board got to Overtown, they had been at work on the expressway for nearly a decade and had tired of the seemingly endless battles with Miami officials over routes, exits, elevations, and clearances. The Florida State Legislature compounded the problem by twice failing to provide funds for relocation efforts.

If the choice of the expressway route illustrated the price of expediency, urban renewal illustrated the price of good intentions. All of the urban renewal officials interviewed for this study claimed that their goal was to improve the quality housing in Overtown-because the issue of housing conditions in Overtown had been on the public agenda for some 40 years. However, Miami was not a typical example of urban renewal. By the time the agency was set up in 1963, the faults of urban renewal in other cities had become abundantly clear, particularly the criticisms of urban renewal as "Negro removal" (Anderson, 1964; Gans, 1965). Urban Renewal Agency projects in Overtown were exclusively low-rise housing developments for local residents and local churches were left standing, since they served as key community institutions. No land in Overtown was taken for other projects-such as civic centers, government buildings, or high-rise housing projects - as was commonly the case in other cities 
(City of Miami, 1965, 1966; Metropolitan Dade County Planning Department, 1963). Whatever its eventual result, the goal of urban renewal in Overtown was to improve the condition of housing, rather than displace a neighborhood to make way for downtown expansion.

But these good intentions were not enough to prevent urban renewal from devastating Overtown. Oliver Kerr, an Irishman who served as a priest at St. Francis Xavier Catholic Church in Overtown from 1967 to 1971, described the area as a "a seething mass of humanity" when he arrived. Though a terribly impoverished neighborhood, Overtown retained a durable community nucleus of respected middle-class business owners and homeowners. Urban renewal changed that. Although the local urban renewal officials Kerr dealt with sincerely wanted to help the area, they were not the only policymakers with a hand in the community. As a result, there was far more destruction in Overtown than there was rebuilding-in effect, Miami repeated the classic mistakes of urban renewal. Kerr recalled vividly that at one point there had been so many existing structures demolished that he could stand on the front steps of his church and see clearly almost every other church in the neighborhood. More important, it took another two and a half years before construction began on new residential buildings in the area. The problem, according to Kerr, was a change in urban renewal and housing policy in Washington, DC. While decision-makers at the national level sorted out their new policy, Overtown lost about half of its population due to urban renewal and expressway displacement. This meant that businesses lost customers, resulting in the evisceration of the local economy: the number of businesses along 2nd and 3rd Avenues, the economic heart of the area, plummeted from 274 in 1967 to 148 in 1971. Thus, while not intended, the combination of expressway construction and urban renewal devastated the local economy, killing off the already weakened local institutions that provided a sense of collective mobility and cultural independence for what remained of the community.

\section{TRANSPORTATION POLITICS IN MIAMI: WHY OVERTOWN COULD NOT DEFEND ITSELF AGAINST DEVELOPMENT}

In retrospect, there were certainly some policy successes that accompanied the transportation projects in the Miami area. There is no doubt that the Miami business elite thought I-95 and I-395 had positive impacts for the broader community. To a certain extent, the new highways slowed the decline of the downtown area, at least as a center for high-rise office buildings. Tourists and local workers could move quickly from home to work or from the airport to hotels, and trucks had better access to the entrance to the port. However, it is also clear that a viable (if not quite thriving) working- and middle-class black community with all the institutions necessary for survival and autonomy was destroyed by the cumulative impacts of transportation projects and urban renewal. A community might survive the impact of several small-scale projects. But when $40 \%$ of the population is displaced within a period of five years (1965-1970), when the number of business establishments drops by half during the same period, and the rate of homeownership declines over $60 \%$, a community will not be able to sustain itself. The expressway and urban renewal were so large that they created a kind of siege atmosphere in Overtown. Buildings were destroyed on nearly every street in the core residential and commercial areas of the community, giving a very real impression that the community was being dismantled.

However, it is also clear that there was more to the destruction of Overtown than I-95 and urban renewal. Data presented in Table 6 demonstrates what was happening in other southern cities that built urban highways to speed commuters to downtown areas. As part of this study, we analyzed the minority communities directly impacted by the transportation projects in four other cities (Jacksonville, Nashville, New Orleans, and Tampa). In these cities, the minority 
TABLE 6

Changes in Black Population: Overtown and Comparison Communities

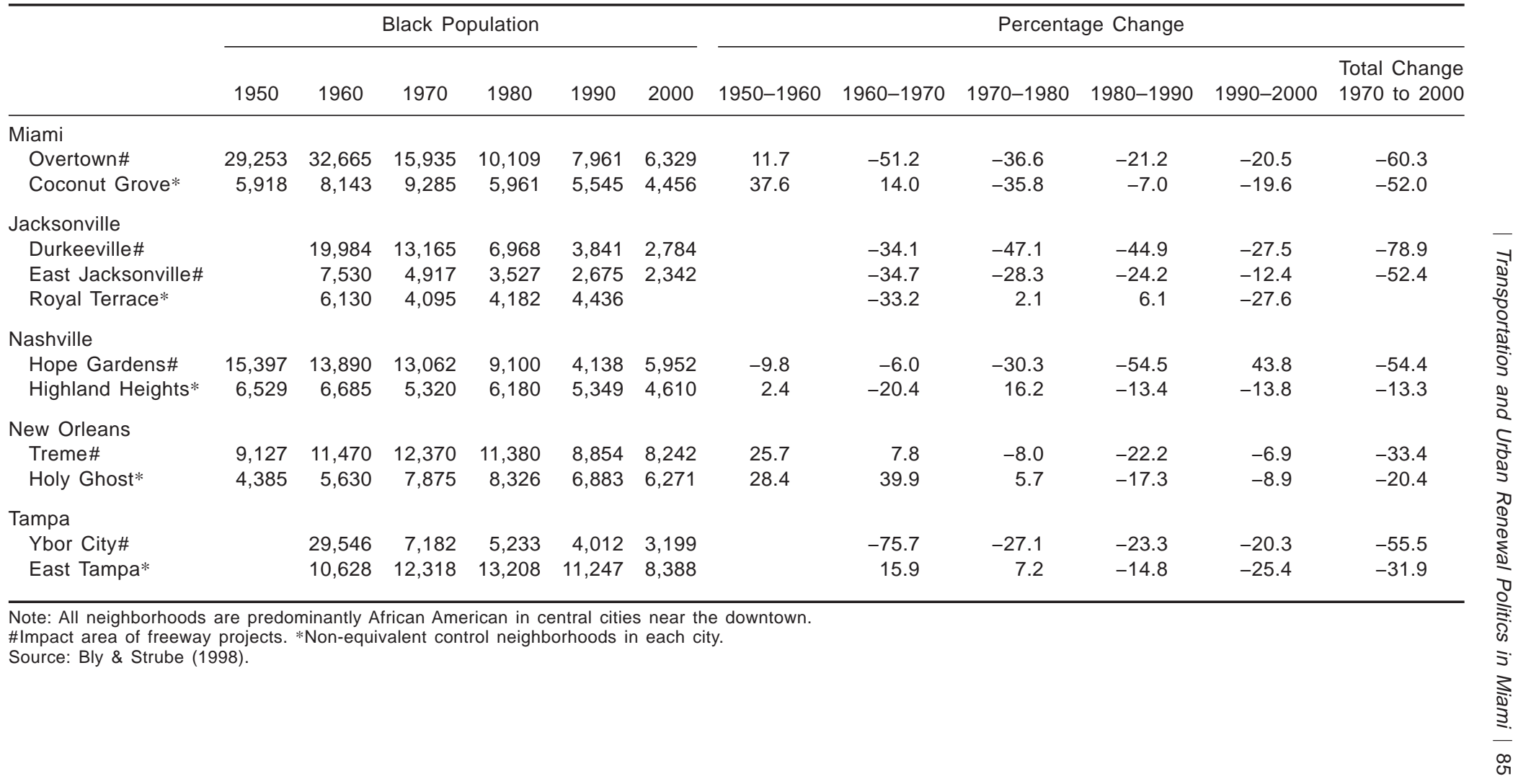


communities impacted by transportation projects did not fair as well as the other minority communities in other parts of their cities. Predictably, transportation projects appear to have had similar results across a number of cities.

Nevertheless, in each of these cities the decline of communities impacted by transportation and urban renewal policies was not as severe as that experienced by Overtown. While interstate highway construction may have produced similar negative effects on minority communities, it is also clear that Overtown suffered disproportionately in the years immediately following highway construction. Although Overtown has been the subject of numerous studies, there is little evidence that the city of Miami ever used CDBG funds, UDAG federal grants, or other federal and state resources to assist in the redevelopment of the area (Dluhy, Cattan, Revell, Strube, \& Wong, 1998). The only investment made during the post-transportation-project period (other than urban renewal) was the building of 500 public housing units in the area. The disinvestment cycle, which began in the late 1960s after the highway projects were almost complete, has never really been reversed despite the completion of numerous strategic plans. The Downtown Development Authority, the most active redevelopment agency in the city of Miami, continues to this day to exclude Overtown from its geographic boundaries.

The one exception to this observation is the Folklife Village, an African American development that is promoting inner-city residential living and entertainment. At the time of this writing, the primary constituency advocating the redevelopment of Overtown is a small group of blacks who moved out of the area years ago but who remain interested in its economic development and future, although other institutions have begun to play a role as well. Given the current financial and budgetary problems of the city of Miami, however, it is unlikely that it will invest any resources in the area in the near future (Dluhy \& Frank, 2001). As government agencies show little inclination to invest public funds in the community, it appears that Overtown's future will be shaped by a combination of private market forces and non-profit organizations. And it is unlikely that private investors will be drawn to Overtown without the assistance of public subsidies and major tax incentives.

\section{SEEKING A FUTURE FOR OVERTOWN IN AN ERA OF POLITICAL UNCERTAINTY}

Putting the restoration of Overtown on the public agenda in Miami-Dade County political arena has taken nearly 30 years and even today it remains unclear whether a concerted effort to revive the area will ever take place. In light of the central role that Overtown played in the life of Miami's black community for most of the twentieth century, it is important to ask why the city of Miami, Miami-Dade County, and FDOT have not offered adequate assistance to mitigate the impacts of I-95/395 and urban renewal. To be sure, the delays in completing urban renewal plans made the impact of residential displacement far more pronounced than it otherwise would have been. But those delays in mitigation continued well beyond the early 1970s. A more comprehensive answer to this question lies in the difficulty of focusing attention on this once significant black neighborhood in the ethnically and geographically fragmented political environment of metropolitan Miami (Becker \& Dluhy, 1998). It is helpful to identify four discrete policy phases in Overtown, ranging from the mid-1930s through the 1990s, each revealing a different set of political problems and issues that contributed to the neglect and decay of Overtown.

During Policy Phase 1 (from the 1930s through the mid-1960s), the poor quality of housing remained the central policy problem in Overtown. After three decades of failure to address the housing issue, the expressway and urban renewal apparently solved part of the housing crisis-poor-quality houses were simply torn down. The number of high-density slums were 
cut in half; the slumlords were no longer as influential as they had been in the 1930s, 1940s, and 1950s; and the new cooperative housing created during urban renewal was neither as crowded nor as shoddy as the shotgun shacks or concrete monsters that once characterized most of the dwellings in Overtown.

Policy Phase 2 (late 1960s to 1980) can be described as a period of political inaction for Overtown. Because the problem of housing was such a high profile issue, it took several years for city and county leaders to appreciate that Overtown had a new set of problems as a result of urban renewal. The elitism of local planners likewise slowed recognition of the problems produced by urban renewal. Throughout the 1960s and into the early 1970s, the professional planning community focused intently on physical determinism, resulting in very narrow goals for the public policies that affected Overtown: 1) the expressway was designed to move people efficiently, and 2) urban renewal was designed to improve the physical structures and appearance in the neighborhood.

In these narrow terms, both policies succeeded. As the last of the urban renewal projects was being completed in Overtown in the mid-1970s, the Downtown Development Authority began to focus its attention on other parts of the central city. It was during this period that the southern part of downtown Miami boomed. Although Overtown was not a high priority during the 1970s, planners were beginning to recognize the unintended consequences of previous policies, but still in physical terms (Jacobs, 1961; Mumford, 1963). In 1971, for example, the Metro-Dade Planning Department recognized the physical destruction that had occurred in Overtown (Metropolitan Dade County Department of Planning, 1971). However, it would take more than a decade before they turned their attention to economic and community revitalization in Overtown and redefined the nature of the policy problem.

During Policy Phase 3 (1980 to 1998), economic revitalization and community restoration became the new central concerns of Overtown activists. Local community activists began to argue forcefully that tearing down slums had simultaneously destroyed an economically and culturally active community. Urban unrest contributed to the re-evaluation process promoted by local activists. The 1980 riot, although centered in Liberty City, also affected Overtown. By then, it was no longer possible to argue that poor housing in the area was the central policy problem (Overtown Blue Ribbon Committee, 1984). Political leaders in the city and county were thus forced to look for other explanations for the continuing decline of Overtown. As the importance of housing conditions slipped from memory, local activists formulated a new political agenda: reparations for past injustices. In order to organize political support around the reparations agenda, it was necessary to establish blame and assign responsibility for correcting past policy failures.

Just as policy re-definition occurred, however, Miami's political landscape underwent a dramatic reconfiguration that further reduced the power and influence of the black community in local policy-making (Bowie \& Stepick, 1998). The Mariel boatlift, which brought over 120,000 Cuban refugees to Miami in 1980, forced the city and county to focus available resources on assimilating refugees, who constituted (at least for a time) a far more pressing public need than Overtown. Perhaps more important, ethnic diversity became a central feature of local politics in the wake of the boatlift. As Portes and Stepick (1993) argued, prior to Mariel, the CubanAmerican community was concerned primarily with advancing economically and fighting Castro. Due to the virulently anti-immigrant response of the Anglo establishment to the Mariel refugees, even long-time Hispanic residents of Miami re-emphasized their ethnicity, thus "transforming the exile community into a self-conscious ethnic group that organized effectively for local political competition" (Portes \& Stepick, 1993, p. 37; Hill, Moreno, \& Cue, 2001). Within a few years, Cuban-Americans held the mayor's posts in the cities of Miami and Hialeah and replaced both blacks and Anglos in an increasing number of senior administrative posts. 
By 1990, there were about a million Hispanics in Miami-Dade County (nearly half of the population), far outnumbering the 371,691 non-Hispanic blacks and recent census figures show that Hispanics have now surpassed blacks as Florida's and the nation's largest minority. This demographic dominance has translated directly into political power. Currently, CubanAmericans hold a majority of seats on the Miami City Commission, a plurality of the seats on the county commission, and one-third of the county's seats in the state legislature (Grenier \& Castro, 1998). During a period in which other major American cities have seen blacks emerge as a major political force, Miami's African American community has been pushed to the third tier on the ladder of power, well below both Cuban- and Anglo-Americans.

More important for Overtown, this reconfiguration of local political power had a profound effect on policy-making. Having only recently achieved political power, Cuban-Americans understandably had little interest in sharing their newly acquired authority with blacks (Crouchier, 1997). Leaders in the Hispanic power structure generally have little sense of connection to the historical struggles of the black community in the United States. As one group of the county's Hispanic employees recently put it, "Anglos historically are guilty of enslaving and degrading blacks for centuries; they owe blacks. But, folks, we Hispanics owe blacks nothing" (Grenier \& Castro, 1998, p. 47). This attitude makes the problem of mitigation in Overtown especially difficult because the principal argument for devoting resources to its restoration is historical. The Cuban-Americans who now run local governments were not in power when Overtown was destroyed (few were even in the country) and, therefore, feel no responsibility to redress the historical wrong in the form of reparations. And given the levels of poverty and social distress in the Cuban community itself, shifting resources to a small black neighborhood makes little sense, politically or as a policy choice.

During Policy Phase 3 Overtown has also had to contend with its own marginal role within South Florida's black community. Since the 1950s, the locus of black population in the county has shifted northward. By 1970, thanks in small part to urban renewal and in large part of the in-migration of native blacks, Liberty City, Carol City, and Opa Locka had all surpassed Overtown in terms of population. By 1980, Overtown's 10,109 residents (less than a third of its peak population in 1960) accounted for a minuscule 3.6\% of the county's black residents. Other neighborhoods increasingly demanded what little attention policymakers were willing to devote to the black community. Other policy issues within the broader black community have also taken precedence over the redevelopment of Overtown. Only months after Mariel, for example, the Liberty City area was the center of an extremely violent and destructive riot after white police officers killed a black motorist in a confrontation following a traffic incident (Porter \& Dunn, 1984). As a result, not only did police-community relations, long a simmering problem in the black community, move to the top of the political agenda, but also economic development efforts necessarily focused on the riot-torn sections of Liberty City (Dunn, 1997). And while the riot made community and economic development the new focus of policy efforts, relatively speaking Overtown was simply not as important as it used to be.

Divisions within the black community have likewise thwarted efforts to put the restoration of Overtown on the public agenda. African Americans in Miami-Dade County are fragmented into nearly 20 distinct and often widely separated neighborhoods. This geographic fragmentation disperses black political power and discourages solidarity on policy matters. The black middle class, who is now concentrated outside of inner-city neighborhoods, has also developed its own set of political concerns, unrelated to either the contemporary or historical problems of Overtown.

The diffusion of black political power has been further complicated by immigration. Relations between native African Americans and a rapidly growing population of Caribbean immigrants (especially from Haiti) are strained at best, thus preventing the creation of a larger 
political coalition among black groups. More important for Overtown, the ethnic tensions of a generation ago continue to shape the debate over how to address the effects of expressway construction. Overtown's former elite was largely of Bahamian descent. This exile population, which began to move out of the area in the 1930s, has always looked upon more recent residents as interlopers. The exile community and current residents do not always see eye-toeye on policy matters, resulting in an on-going tug-of-war over place-based versus peoplebased remedies. There are, in other words, two groups that have claims on Overtown-the residents who live there now and an absentee community of residents who have not lived there, in many cases, for over 40 years - and these groups continue to disagree over the best ways to revitalize the community. In the context of Miami's ethnic political battlefield, those disagreements nearly insure that Overtown will continue to be denied the attention and resources necessary to mitigate the effects of the previous half-century of public policies (Gale, 1999).

That may be changing, however, paving the way for Policy Phase 4 in Overtown (1998 to present). For three decades after the construction of I-95, Overtown had no direct political representation on the Miami City Commission or the Miami-Dade County Commission. Recently, however, both jurisdictions have created single-member districts with African American representatives who have both shown a willingness to fight for resources for Overtown. These two representatives provide the most encouraging examples of potential progress for Overtown in the future. Both may be able to leverage pork barrel projects into Overtown and thus incrementally improve the community over time.

\section{BEYOND NOSTALGIA: THE FUTURE OF OVERTOWN AND OTHER COMMUNITIES LIKE IT}

In many ways, Overtown is another example of an inner city black neighborhood destroyed by policy decisions and economic forces associated with absentee ownership, draconian building code enforcement, urban renewal, and expressway building. This now familiar story has given rise to new approaches to massive transportation projects and urban renewal policy. Community participation is now an integral part of transportation planning and social and environmental impact analyses are often legally required preludes to mitigation efforts that follow quickly on the heels of large-scale construction projects. The planning of Miami's Metro-Rail in the 1970s and the current East-West Multi-Modal rail line both involved a far greater level of community input than either I-95 or urban renewal. The re-routing of the East-West project shows just how influential community input can be. Given the increasing importance of community participation in transportation planning, one might even conclude that the lessons of Overtown, and the scores of other disrupted black communities in America's inner cities, have already changed the way transportation planners do business, even though retroactive mitigation for previous policy impacts has yet to be undertaken.

An equally obvious lesson is that revitalization policies need to be enacted either while transportation projects are being completed or a short time afterward. Once the decay cycle sets in, it is difficult to reverse, although earlier (if not immediate) intervention might have saved more of the community's institutions from being destroyed. Policy neglect, in short, appears to have guaranteed further decay. Indeed, were it not for the recent establishment of singlemember districts at the city and county levels, it seems likely that Overtown would continue to be neglected by Miami's current political regime. Representation, rather than expert planning, appears to be the only way that Overtown has been able to attract the policy attention it is seeking. But the lessons of Overtown extend beyond the obvious need to involve the community in transit planning and to react quickly to mitigate the impacts of transportation projects on minority communities. 
Because Overtown is now remembered so fondly (partly because its destruction is now widely interpreted as a deliberate act, and because the area has been the subject of numerous studies) debate over the best way to secure its future remains an active political issue in Miami. Local governments can only handle a few problems at a time and a poor city like Miami is even more restricted in its ability to address the contemporary challenges of its minority neighborhoods, let alone redress the effects of policies that occurred decades earlier. Given the obstacles to building a consensus around a redevelopment strategy or achieving consensus over who really represents the community, adequately mitigating the impact of I-95 will likely take many more years. Because Miami politics continue to be fragmented along racial and ethnic lines, Overtown will undoubtedly remain the target of half-hearted and under funded policy measures that will probably have no long-term or widely felt impacts. What, therefore, can we offer as policy options for Overtown and communities like it? With Overtown, the most unrealistic vision is to think that a viable middle- and working-class African American community can be recreated on the basis of the nostalgia of former residents. The physical reconstruction of the community as it existed 40 years ago would not be possible without major structural changes in the present freeway system. Upwardly mobile African Americans have already relocated to other neighborhoods in the region. Indeed, data from the 2000 census shows that the movement of blacks away from the inner city has accelerated, with large segments of the middle class abandoning former strongholds like Liberty City and Brownsville for residential areas in northern Miami Dade County and southern Broward County (Viglucci, 2001). Nevertheless, there are several viable policy options for encouraging the redevelopment of Overtown that should be considered, even in light of the formidable barriers (political, demographic, and historical) to effective action.

1. The Free Market and Infrastructure Approach for Overtown. Economists such as Porter (1997) argue that government operates most effectively when it does not try to dictate land uses or types of communities. Rather, government should concentrate on infrastructure and wait for the market to respond. As the reasoning goes, improve the streets, sewers, utilities, clean up the area, make it safe, enforce the codes, and otherwise concentrate on the physical infrastructure. If Caribbean immigrants find the area attractive, then they may be the next wave of residents and in the long run, perhaps a viable Caribbean community will evolve. Alternatively, because Overtown is on the fringe of the Central Business District, infrastructure upgrades may encourage spillover development. In this case, it appears that high-rise apartment buildings and condominiums might be the natural outgrowth from the CBD. Simply put, let the market dictate the next phase of development for Overtown and concentrate on making the area ripe for investment. Even though Overtown now has political representation in city and county government, Hispanics still dominate local politics and government resources as discussed above. Under these circumstances, black politicians should be able to get limited pork barrel or infrastructure improvements for the area. It is unlikely that there will be major amounts of money available at any one point in time, but a series of smaller projects might be possible and they could be scheduled over an extended period of time. For example, 39\% of the land in Overtown is now vacant (17\% is empty lots and $22 \%$ is under the expressways) (Dluhy, Cattan, Revell, Strube, \& Wong, 1998). Vacant lots are littered with trash, abandoned cars, fallen structures and other unsightly objects. The areas underneath the expressway structures are a no man's land. They have the same appearance as the vacant lots but they also provide shelter for several homeless squatter settlements. At a minimum, these areas need to be cleaned up and landscaped to make them ripe for reinvestment and redevelopment. Other projects, like improving the internal circulation system in the area (i.e., making sure closed streets are reopened and the four quadrants of the community are reconnected), removing graffiti, condemning and demolishing abandoned buildings, and upgrading the parks and public 
spaces would all enhance the physical appearance of the community and make it more desirable for redevelopment.

2. Racial Heritage Tourism and Redevelopment. Racial nostalgia currently is responsible for an extremely small development in the southeast corner of Overtown where the old Lyric Theatre has been restored. Other historical landmarks have been identified by the Black Archives Foundation of Miami in the hope that these buildings will eventually be restored and that this sub-area of Overtown would then become a historical district celebrating black culture. As Boyd (2000) documents, many large American cities are currently in the process of restoring small areas of their inner cities that have been identified as important historical landmarks for black history and culture. Some believe that these historical districts may eventually become a stimulus for broader economic redevelopment. In terms of the remaining historical structures in Overtown, there is only a small area of what used to be the business district that would be feasible to restore, probably about 10 to 15 buildings. Because of the other negative features of Overtown described above, it has taken a great deal of private fund raising and patchwork government funding over the last decade to complete the renovation of the Lyric Theatre and the local real estate market has not yet shown any interest in capitalizing on this one small historic preservation project to create a larger tourist-oriented entertainment area. Nevertheless, local black politicians can incrementally help with this building-by-building approach and hope the day will come when the market kicks in. Boyd (2000) envisions black culture and history as the driver of the redevelopment process in many inner city neighborhoods. The strategy seems to be to redevelop the historical area without allowing encroachment from the surrounding city neighborhoods or from white developers. This is partially a market decision, but the heritage and identity of the neighborhood would need to be established in the early stages and the buildings protected. Historical zoning and government funds would be needed to help the historical redevelopment process along. Again, black politicians could help with these tasks. If this process ever gets started, it will also be important to prevent racial displacement. For some, that may mean that middle-class blacks would be welcome in the revitalized area but not other racial or ethnic groups (Boyd, 2000).

3. Clearing Large Portions of the Community. Another possibility for Overtown would be to finish the job initiated by urban renewal and expressway building in the 1960s and complete the clearing of the community. Some argue that this could be done in tandem with a HOPE VI project or new urbanism, housing infill project. Because there is so much vacant land, such poor quality housing remaining (i.e., concrete monsters), and so many abandoned buildings, it might be wiser to level large sections of the community and have in place a generous relocation and displacement program. Black entrepreneurs like former basketball star Magic Johnson have gone into inner city neighborhoods (i.e., Los Angeles) and cleared areas and then constructed entertainment complexes and other commercial developments. Largescale government clearance projects are unlikely and government funding for these kinds of projects are almost non-existent in the current political climate. If clearance of large portions of Overtown is to take place, it will have to be as a result of some private-public joint venture where the private sector puts up most of the money and the public sector assists in the regulatory, building and zoning, and tax abatement areas. To date, no large developers or entrepreneurs have been interested in Overtown and this approach might be less feasible now because most of the largest developers in the Miami area are Latin and have shown more interest in redeveloping older, run down Latin neighborhoods. At this time, it would be necessary to assemble a substantially large track of land to be able to develop an industrial park, office park, or condominium or townhouse development that would eliminate the older buildings and the other characteristics of urban blight which scare big investors away. At this time, big developers have not yet found Overtown. Unfortunately for Overtown, the Brickell financial area 
to the south of downtown Miami is booming and the Omni area to the northeast of the downtown area is now beginning to gentrify. Down the road, the private sector may eventually discover Overtown but in the short run, there appears to be little interest.

4. Encourage Small-Scale Housing and Retail Development. The John S. and James L. Knight Foundation recently announced a three-year, \$12 million grant package for revitalization projects in three Miami neighborhoods, including Overtown. This includes \$3 million for the Collins Center for Public Policy (a Tallahassee-based think tank) for analysis of investment opportunities, purchase of land, and provision of construction loans, \$2 million for the Local Initiative Support Corporation for technical assistance on housing and retail projects, $\$ 600,000$ for ten Habitat for Humanity houses, $\$ 500,000$ for a new community center for after-school programs, a health clinic, and nutrition classes, and \$2.5 million for the Trust for Public Land to create a pathway along the Miami River to connect Overtown and Little Havana, as well as other park projects. Building in part on the development philosophy that has had such success on South Beach and on similar efforts in Akron, Ohio, this initiative aims to identify and develop the community's hidden assets (such as historic buildings) and invest in quality-of-life improvements for existing residents. By investing capital in smaller increments and avoiding large-scale projects that would cause displacement, this approach seeks to revitalize neighborhoods at the grassroots level.

Similar efforts have certainly shown results in places like the South Bronx. Assisted by lower crime rates, deregulation of city bureaucracies, and the appearance of competent neighborhoodbased non-profit organizations, functioning private retail markets have re-emerged along innercity business strips (Grogan \& Proscio, 2000). However, Overtown does not appear to have as many hidden assets as South Beach, which is the second largest historic district in the country, and may not be able to transform the few that it has into a major resource, in spite of the potential for some tourism-led redevelopment. (This may be especially so, as tourism in Miami has suffered in the aftermath of the September 11, 2001 terrorist attack on the World Trade Towers). Although several local CDCs have been around for decades, they do not have an impressive record of achievement. There is also considerable competition among the county's 40 CDCs for scarce funding. Nevertheless, with the help of Knight Foundation funding and LISC expertise, this approach may be able to target resources to provide a critical mass of activity for mixed-use redevelopment—renewed housing and small-scale retail—in a limited area of Overtown.

5. Reinforce and Redevelop the Four Quadrants Created by the Expressway System. The expressway system carved the original Overtown into four distinct areas, cutting off whole parts of the original community from other parts. Only a few streets today can be used to go from one part of the community to another. Without a car, it is impossible for people to move easily between different parts of the area. Children in one of the large public housing projects have to go at least eight blocks out of their way to get to school because the school is on the other side of the expressway. Residents living west of the expressways have difficulty getting to the small business district that still remains on the east side of the expressway. In short, the circulation problems created by the physical expressway structures have made it impossible to have the type of integrated community of the past remembered by the exiled population who grew up in Overtown. If residents and former residents with a vested interest in Overtown could agree to accept the fate of the old Overtown and give up the notion of recreating it, then perhaps a more realistic solution would be to consider incorporation of the four quadrants into their adjacent communities. For example, the northwest quadrant could be better developed as high-rise condominiums, rental units, and townhouses because this area is adjacent to the large Jackson Memorial/University of Miami Medical complex. These highdensity residential facilities could be a natural home for medical complex employees. In this 
quadrant, clearance and new building would seem to be the order of the day. In the southwest quadrant, there are still quite a few attractive single-family homes. These homes have largely been built since the 1920s and have a distinct south Florida architecture. Renovation and other upgrading in this area would give residents who want a single family home and want to be close to the downtown, a decent place to live. This neighborhood is currently racially mixed and has few black historical and cultural activities. It seems feasible that the city and county might promote redevelopment by using government funds and community reinvestment strategies to renovate and improve the quality of the housing of this residential neighborhood that borders the Miami River.

The southeast quadrant, which is contiguous to downtown Miami, is where the Lyric Theatre is located and where some historical commercial buildings and churches still remain. This area should continue to receive government help where possible to create a small historic district that emphasizes entertainment, restaurants, and small shops that cater to black culture and tourism. Given the geographic size of this quadrant, there is not much room available for housing here, so the historical area should emphasize business and religion. Finally, the northeast quadrant contains some of the worst housing in the city including the concrete monsters and other poorly maintained rental units. Additionally, the area borders the FEC railroad tracks and contains quite a few small warehouses and other industrial buildings. This area has the natural locational advantages to become an industrial park. Because the value of the housing in this area is minimal and of no historical significance, it seems reasonable to level most of the area and re-do it as an industrial park. This strategy would leave viable industries and warehouses in place but eliminate the worst residential and industrial property. This might also be a politically popular approach for this quadrant since this area contains the drug trade and some of the highest crime rates in the city.

Overtown can never be the community so fondly remembered by the prior residents, but it can be helped. In our judgment, the four-quadrant approach offers the most promise because it connects each sub-area of the old Overtown to an adjacent community, which is currently viable and stable. The southeast quadrant and historical district can reinforce the nostalgia and interest in racial heritage while the rest of the original Overtown can become a more integral part of their adjacent communities. In all of this, Porter (1997) may be right about government-it needs to concentrate mainly on infrastructure and let the normal market forces, assisted by competent, adequately funded non-profits, drive redevelopment. The message of this analysis is that other inner neighborhoods impacted by transportation policy face similar dilemmas to Overtown, but they must face the reality of economic redevelopment without making nostalgia for a lost community a barrier to redevelopment. Although those communities were often subjected to public policies that effectively destroyed them, the historical circumstances that allowed them to prosper cannot be reconstructed. And where the physical damage of the past is so extensive, as is the case in Overtown, the community may exist only as a memory. The value of that lost past can and should be recovered in some measure, but revitalization must proceed realistically. Racial heritage tourism offers one viable, though limited, approach to the future development, but it must be supplemented with other market-oriented solutions that take into account the very real barriers to inner-city revitalization.

\section{REFERENCES}

Anderson, M. (1964). The federal bulldozer: A critical analysis of urban renewal, 1949-1962. Cambridge, MA: MIT Press.

Becker, F. W., \& Dluhy, M. J. (Eds.). (1998). Solving urban problems in urban areas characterized by fragmentation and divisiveness. Greenwich, CN: JAL Press. 
Blackside. (1990). Eyes on the prize, back to the movement (1979-mid-1980s). Alexandria, VA: PBS Video.

Bly, A., \& Strube, J. (1998). Comparing Overtown, Miami with neighborhoods in other cities. In M. Dluhy, P. Cattan, K. Revell, J. Strube, \& S. Wong (Eds.), The historical impacts of transportation projects on the Overtown community: Final report. Miami, FL: FIU Institute of Government.

Bowie, S., \& Stepick, A., III. (1998). Diversity and division: Ethnicity and the history of Miami. In F. Becker \& M. Dluhy (Eds.), Solving urban problems in urban areas characterized by fragmentation and divisiveness, pp. 19-32.

Boyd, M. (2000). Reconstructing Bronzeville: Racial nostalgia and neighborhood redevelopment. Journal of Urban Affairs, 22(2), 107-122.

Cattan, P. (1998). Profile of Overtown and surrounding areas: 1950-1990. In M. Dluhy, P. Cattan, K. Revell, J. Strube, \& S. Wong (Eds.), The historical impacts of transportation projects on the Overtown community: Final report. Miami, FL: FIU Institute of Government.

City of Miami. (1965). Community renewal program. Miami, FL: Author.

City of Miami. (1966). City of Miami community renewal program: Phases 2 and 3-community renewal goals and detail resources needs in Miami. Miami, FL: Author.

Crouchier, S. L. (1997). Imaging Miami: Ethnic politics in a postmodern world. Charlottesville, University of Virginia.

Dluhy, M., Cattan, P., Revell, K., Strube, J., \& Wong, S. (1998). The historical impacts of transportation projects on the Overtown community: Final report. Prepared by the Institute of Government, Florida International University, for the Metropolitan Planning Organization of Miami-Dade County.

Dluhy, M., \& Frank, H. (2001). The Miami fiscal crisis: Can a poor city regain prosperity? Westport, CT: Greenwood Publishing.

Dunn, M. (1997). Black Miami in the twentieth century. Gainesville, FL: University Press of Florida.

Gale, D. E. (1999). Miami: The Overtown neighborhood: A generation of revitalization strategies gone awry. In W. D. Keating \& N. Krumholz (Eds.), Rebuilding urban neighborhoods: Achievements, opportunities, and limits (pp. 159-176). Thousand Oaks, CA: Sage Publications.

Gans, H. (1965, April). The failure of urban renewal: A critique and some proposals. Commentary, 39(4), 29-37.

Grenier, G., \& Castro, M. J. (1998). The emergence of an adversarial relation: Black-Cuban relations in Miami, 1959-1998. In F. Becker \& M. Dluhy (Eds.), Urban problems in areas characterized by fragmentation and divisiveness (pp. 33-55). Greenwich, CN: JAL Press.

Grogan, P. S., \& Proscio, T. (2000). Comeback cities: A blueprint for urban neighborhood revival. Boulder, CO: Westview Press, 2000.

Hill, K. A., Moreno, D. V., \& Cue, L. (2001). Racial and partisan voting in a tri-ethnic city: The 1996 Dade County mayoral election. Journal of Urban Affairs, 23(3-4), 291-307.

Jacobs, J. (1961). The death and life of great American cities. New York, NY: Vintage Books.

Metropolitan Dade County Department of Planning. (1963). General neighborhood renewal plan: Central Miami urban renewal area. Miami, FL: Author.

Metropolitan Dade County Department of Planning. (1971). Multiple use opportunities for Midtown Miami: East-West Expressway-Interstate 395 Midtown Interchange to Biscayne Bay. Miami, FL: Author.

Metropolitan Planning Organization of Miami-Dade County (MPO). (1996a, March 7). Public meeting video recording.

Metropolitan Planning Organization of Miami-Dade County (MPO). (1996b, March 21). Public meeting video recording.

Mohl, R. A. (1993). Race and space in the modern city: Interstate-95 and the black communities in Miami. In A. R. Hirsch \& R. Mohl (Eds.), Urban policy in twentieth-century America. Rutgers University Press.

Mohl, R. A. (1995). Making the second ghetto in Metropolitan Miami, 1940-1960. Journal of Urban History, 21, 395-427.

Mumford, L. (1963). The highway and the city. New York, NY: Harcourt Brace Jovanovich.

Overtown Blue Ribbon Committee. (1984). A report on the measures of the 1982 Overtown riot. 
Porter, M. (1997). New strategies for inner city economic development. Economic Development Quarterly, 2(1), 1-19.

Porter, B. D., \& Dunn, M. (1984). The Miami riot of 1980: Crossing the bounds. Lexington, MA: Lexington Books.

Portes, A., \& Stepick, A. (1993). City on the edge: The transformation of Miami. Berkeley, CA: University of California Press.

Sugrue, T. J. (1996). The origins of the urban crisis: Race and inequality in postwar Detroit. Princeton: Princeton University Press.

Vernon, R. (1959). The changing economic function of the central city. New York, NY: Committee for Economic Development.

Viglucci, A. (2001, April 22). Suburbs beckon as blacks prosper. Miami Herald, 1A, 21A.

Wong, S. (1998a). Historical overview of Overtown. In M. Dluhy, P. Cattan, K. Revell, J. Strube, \& S. Wong (Eds.), The historical impacts of transportation projects on the Overtown community: Final report. Miami, FL: FIU Institute of Government.

Wong, S. (1998b). Mitigation strategies: Transportation and economic development. In M. Dluhy, P. Cattan, K. Revell, J. Strube, \& S. Wong (Eds.), The historical impacts of transportation projects on the Overtown community: Final report. Miami, FL: FIU Institute of Government.

Woodbury, C. (1953). The future of cities and urban redevelopment. Chicago: University of Chicago Press. 